\title{
A Centennial: Discovery of Paracoccidioides brasiliensis
}

\author{
Célia Maria de Almeida Soares · Maria José Soares Mendes-Giannini • \\ Maria Sueli Soares Felipe · Vishnu Chaturvedi
}

(C) Springer Science+Business Media B.V. 2008

The year 2008 is the centennial of the discovery of paracoccidioidomycosis and its fungal etiology by the distinguished Brazilian researcher Adolpho Lutz [1]. Subsequent studies by many dedicated Brazilian and other Latin American investigators have led to the formal recognition of Paracoccidioides brasiliensis as a taxonomically valid entity, which is solely responsible for paracoccidioidomycosis. Interestingly, two other major pathogens Histoplasma capsulatum and Coccidioides posadasii, which overlap in the same geographical areas, were also recognized early in these

C. M. de Almeida Soares

Guest Editor

Laboratorio de Biologia Molecular, ICB II, Campus II, Universidade Federal de Goias, 74001-970 Goiania,

Goias, Brazil

M. J. S. Mendes-Giannini

Guest Editor

Departamento de Análises Clínicas, Faculdade de

Ciências Farmacêuticas, UNESP, R. Expedicionários do

Brasil 1621, 14801-902 Araraquara, SP, Brazi

\section{S. S. Felipe}

Guest Editor

Laboratório de Biologia Molecular, Departamento de

Biologia Celular, Universidade de Brasília, 70910900

Brasilia, DF, Brazil

V. Chaturvedi $(\bowtie)$

Editor-in-Chief

Mycology Laboratory, Wadsworth Center, New York

State Department of Health, Albany, NY, USA

e-mail: eic@mycopathologia.net parts of America. All three of these primary pathogens display common themes in their complex ecology, morphogenetic transition in vivo, endemic distribution, association with mammalian species, common asymptomatic infections, and rare progression to more debilitating diseases. Paracoccidioidomycosis also has a noteworthy social aspect as it overwhelmingly afflicts economically disadvantaged rural populations. Thus, the lessons learned from ongoing studies on ecology, evolution, virulence, rapid diagnosis and treatment, and vaccination for $P$. brasiliensis might have important implications for researchers working with fungal pathogens in other parts of the world.

There is a vigorous scientific tradition in South America most prominently in Brazil that has ensured that $P$. brasiliensis and its clinical manifestations remain under close scientific scrutiny. As a result of these efforts, Franco et al. most recently summarized the voluminous literature generated in last 100 years in 1994 in the monograph 'Paracoccidioidomycosis' [2], which was commented by Castañeda in Mycopathologia [3]. The journal has the distinct privilege of being an important medium for dissemination of studies on paracoccidioidomycosis and $P$. brasiliensis, the first article appearing as early as 1943 [4]. Over the years, Mycopathologia has published nearly 90 specialized articles dealing with all aspects of the disease as well as the pathogen. The current special issue continues this tradition with 13 invited articles from leading laboratories in South America. San-Blas and Niño-Vega [5] start off this special issue with an update on modern 
investigative tools that have recently allowed characterization of $P$. brasiliensis taxonomy, cell wall, diagnostics and antifungal targeting. The existent knowledge on the ecology and evolution of this pathogen is synthesized by Bagagli et al. [6] to construct a hypothetical biological cycle of $P$. brasiliensis, which is also reproduced on the cover of this special issue. Benard [7] reviews the intrinsic balance of host-pathogen factors that determine immunopathology of infection and identifies areas of future investigations. The usefulness of murine models to discern important innate immune mechanisms against $P$. brasiliensis infections is summarized by Calich et al. [8] in order to explain how most of the exposed individuals escape from overt disease. Mendes-Giannini et al. [9] provide an exquisite description of $P$. brasiliensis-epithelial cell interactions to underscore the important virulence factors of the fungus. A wealth of data emerging from DNA technology is summarized by Silva et al. [10] with focus on genes putatively related to $P$. brasiliensis-host adaptations. Parente et al. [11] highlight the use of expressed sequence tags (EST) for the discovery of multiple genes that are critical in fungal differentiation and pathogenesis. Puccia et al. [12] focus on the well-characterized immunodominant glycoprotein of $43 \mathrm{kDa}$ (gp43) to estimate the extent of genetic diversity in clinical and environmental strains of $P$. brasiliensis. The current diagnostic approaches for paracoccidiodomycosis are reviewed by Camargo [13] with special emphasis on antigen-antibody tests. Shikanai-Yasuda et al. [14] survey published studies on cancer and paracoccidioidomycosis to highlight the importance of early and accurate diagnosis in clinical management. González et al. [15] review studies aimed at mimicking initial host responses to $P$. brasiliensis conidia in a murine model that has yielded valuable insight about the development of fibrosis. The experimental study by Taborda et al. [16] describes the important and yet previously unsuspected role of melanin pigmentation in virulence of $P$. brasiliensis. Travassos et al. [17] fittingly conclude this special issue with an article on the prospects of vaccination as an adjuvant to chemotherapy based on a peptide derived from gp43. It is our fervent hope that the mix of articles presented in this issue would provide the readers with a big window on the current state-of-the-art of this fascinating pathogen and set up the stage for future explorations of still unknown facets of $P$. brasiliensis.

\section{References}

1. Lutz A. Uma mycose pseudococcidica localisada na bocca e observada no Brazil. Contribuicao ao conhecimento das hyphoblastomycoses americanas. Bras-Med. 1908;22: 121-4.

2. Franco M, Lacaz CS, Restrepo-Moreno A, Negro GD. (editors). Paracoccidiodomycosis. Boca Raton: CRC Press; 1994.

3. Castañeda E. Book review. Mycopathologia. 1995;129:37-8.

4. Artagaveytia-Allende RC, Montemayor L. Estudio comparativo de varias cepas de Paracoccidioides brasiliensis y especies afines. Mycopathologia. 1943;4:356-66.

5. San-Blas G, Niño-Vega G. Paracoccidioides brasiliensis: chemical and molecular tools for research on cell walls, antifungals, diagnosis, taxonomy. Mycopathologia. 2008. doi:10.1007/s11046-007-9040-9.

6. Bagagli E, Theodoro RC, Bosco SMG, McEwen JG. Paracoccidioides brasiliensis: phylogenetic and ecological aspects. Mycopathologia. 2008. doi:10.1007/s11046-0079050-7.

7. Benard G. An overview of the immunopathology of human paracoccidioidomycosis. Mycopathologia. 2008. doi: 10.1007/s11046-007-9065-0.

8. Calich VLG, Costa TA, Felonato M, Arruda C, Bernardino S, Loures FV, Ribeiro LRR, Valente-Ferreira RC, Pina A. Innate immunity to Paracoccidioides brasiliensis infection. Mycopathologia. 2008. doi:10.1007/s11046-0079048-1.

9. Mendes-Giannini MJS, Silva JLM, Silva JF, Donofrio FC, Miranda ET, Andreotti PF, Soares CP. Interactions of Paracoccidioides brasiliensis with host cells: recent advances. Mycopathologia. 2008. doi:10.1007/s11046007-9074-z.

10. Silva SS, Paes HC, Soares CMA, Fernandes L, Felipe MSS. Insights into the pathobiology of Paracoccidioides brasiliensis from transcriptome analysis-advances and perspectives. Mycopathologia. 2008. doi:10.1007/s11046007-9071-2.

11. Parente JA, Borges CL, Bailão AM, Felipe MSS, Pereira M, Soares CMA. Comparison of transcription of multiple genes during mycelia transition to yeast cells of Paracoccidioides brasiliensis reveals insights to fungal differentiation and pathogenesis. Mycopathologia. 2008. doi:10.1007/s11046-007-9078-8.

12. Puccia R, McEwen JG, Cisalpino PS. Diversity in Paracoccidioides brasiliensis. The PbGP43 gene as a genetic marker. Mycopathologia. 2008. doi:10.1007/s11046-0079055-2.

13. Camargo ZP. Serology of paracoccidioidomycosis. Mycopathologia. 2008. doi:10.1007/s11046-007-9060-5.

14. Shikanai-Yasuda MA, Conceição YMT, Kono A, Rivitti E, Campos AF, Campos SV. Neoplasia and paracoccidioidomycosis. Mycopathologia. 2008. doi:10.1007/s11046-0079047-2.

15. González A, Restrepo A, Cano LE. Pulmonary immune responses induced in $\mathrm{BALB} / \mathrm{c}$ mice by Paracoccidioides brasiliensis conidia. Mycopathologia. 2008. doi: 10.1007/s11046-007-9072-1. 
16. Taborda CP, Silva MB, Nosanchuk JD, Travassos LR. Melanin as a virulence factor of Paracoccidioides brasiliensis and other dimorphic pathogenic fungi: a minireview. Mycopathologia. 2008. doi:10.1007/s11046-007-9061-4.
17. Travassos LR, Rodrigues EG, Iwai LK, Taborda CP. Attempts at a peptide vaccine against paracoccidioidomycosis, adjuvant to chemotherapy. Mycopathologia. 2008. doi:10.1007/s11046-007-9056-1. 